\title{
An Examination of the Causal Relationship between Budget Deficit and Inflation: a Case Study of Lao PDR
}

\author{
*Phouthanouphet Saysombath, Phouphet Kyophilavong \\ National University of Laos, Vientiane, Lao PDR \\ *phouthanouphet@yahoo.com
}

\begin{abstract}
In this study we try to attempt investigating the dynamic relation between budget deficit and the inflation in the Lao PDR. Using annual data for the period 1980-2010, we apply ARDL cointegration method in conjunction with the structural VAR (SVAR) analysis to provide evidence for both the long and short run dynamics between the variables. We find that there is no long-run relation between the budget deficit and the inflation in Laos. In addition, we also find that there is Granger causality between the budget deficit and the inflation in Laos. The impulse response results in the SVAR model indicate that the budget deficit does not cause inflation but the inflation does cause the budget deficit.
\end{abstract}

Keywords: Budget deficit and inflation; Cointegration; ARDL Bounds Testing; SVAR model

\section{Introduction}

Are government budget deficits inflationary? In the monetary framework, deficits tend to be inflationary. This tendency is because when monetization takes place, it leads to an increase in the money supply and an increase in the rate of inflation in the long run (Gupta, 1992).The argument is that the monetization of deficits is the fundamental reason for the high inflation problems in developing countries. However, these studies are full of contradictions. The empirical evidence on government deficits is inconclusive because of the inconsistency of the theoretical framework and the data sets. In particular, the evidence is quite limited for developing countries. Lao PDR has faced a consistent budget imbalance for three decades. Arguably, these budget imbalances might have played an important role in explaining price fluctuations. During the 1980s and 90s, the critical task faced by the Central Bank of Lao PDR was to control inflation at the targeted level and also to ensure macroeconomic stability. The rate of inflation rose from 6 percent in 1987 to 25 percent in 1988 and 60 percent in 1989. The government has pursued cautious fiscal and monetary policies since the 60 percent inflation of 1989 by trimming the overall budget deficit from over 16 percent of GDP in 1989 to under 10 percent in the 1992/93 fiscal year. Roughly one-third of this reduction was accomplished by improving revenue collection and by reducing expenditures by twothirds. In the late 1990 s, the inflation rate moderately topped out at above $20 \%$. The average inflation for the 2000s was around 10 percent. The year-on-year inflation rose and stood at 18 percent in 2003 due in part to increased government borrowing to finance a widening budget deficit. The inflation rate then declined to below 5 percent in late 2010. A structural shift in the demand for credit and money balances has precipitated rapid growth in the money supply since 1990, with the broad money supply expanding by 49 percent in 1992, 65 percent in 1993, and almost 78 percent in the late 1990s. This growth leads to high inflation the late 1990s, particularly during the Asian Financial Crisis. Although the money supply declined in the 2000s, it has remained relatively high compared to other small economies.

Currently, revenue from the natural resource sector (mining and hydropower), along with international development assistance, are the primary means of financing the government deficit (World Bank, 2012). The natural resource sector has played an increasingly large role in the Lao economy: its share of total revenue rose from 3 percent in 2001 to approximately 20 percent in 2012, and its share of GDP rose from approximately 2.5 percent before 1997 to 15 percent in 2012 . While previous research has investigated the relationship between fiscal deficits and inflation in a number of other countries, to our knowledge there are no studies that have attempted to do so in the Lao context. To address this gap, this paper examines the long-run relationship between budget deficit and inflation in Lao PDR by applying the ARDL bounds testing approach to cointegration, VAR Granger causality, and a structural VAR framework (SVAR), and by using annual time-series data from the World Development Indicator (WDI) covering the period 1980 to 2010. This study contributes to existing research in two ways. First, it is a pioneering effort to establish causality between the budget deficit and inflation in a previously overlooked context, the Lao PDR. Second, we use the ARDL bounds testing approach to cointegration developed by Pesaran, 
Shin and Smith (2001) as well as the VAR and SVAR employed by Narayan, Narayan and Prasad (2008). This paper is organized as follows: Section 2 discusses the literature and evidence from the empirical findings. Section 3 provides the modeling and empirical strategy. Section 4 provides the empirical results and the last section concludes the paper.

\section{Literature Review}

According to Keynesian economic theory, an increase in the budget deficit produces an increase in the real interest rate, which in turn displaces private investment and leads to higher prices. Moreover, financing the deficit generates excess demand that creates inflation. Additionally, governments that run persistent deficits will be financed, and increases in the money supply contribute to inflation in the long run (Sergent and Wallace, 1981). Generally, the two main alternatives at a government's disposal to cover their budget deficits (namely monetary and nonmonetary financing) have a different impact on inflation. Because monetary financing supposes the creation of new money in order to finance budget deficits, it generally has a greater probability of incurring an inflationary increase in prices that depends directly on the destination of the resources collected by governments. If these resources are used to finance investment projects, which induce a raising output, then the original increase in the money supply correlates with an equivalent rise in the quantity of goods and services available for transactions. In other words, the supply on the real market and the increase in the level of prices does not become permanent. On the other hand, if the additional resources are used to finance final consumption expenses, which does not induce subsequent growth in GDP, the increase in the price level becomes long standing, and the monetary financing of the budget deficit is inflationary. A number of studies support this hypothesis (Darrat, 2000; Cevdet, Alpher and Ozmucur, 2001; Solomon and De Wet, 2004; Catao and Terrones, 2003; Chaudhary and Ahmed, 1995; Khan, Bukhari and Ahmed, 2007).

The second solution for financing the budget deficit implies public loans made by governments in order to make up for supplementary expenditures not covered by current revenues. As a result, the public loan does not lead to the unjustified increase in the amount of financial signs that are in circulation, and it does not generally have an inflationary character. The only case where the involvement of money issuing, with all its negative effects, might become possible is when the indebtedness of the government is accepted as a viable solution in the context of covering the cash deficits of the treasury by loans from the central bank. Thus, if the government meets with financial difficulties, then in order to incur expenditures, it can resort to the central bank that is required to lend it some money to temporarily cover the deficit of the public treasury in exchange for issuing some treasury bills. If the government does not succeed in cashing in current revenues to pay back this loan, then the money stock might unjustifiably increase. Several empirical studies have some success in establishing a statistically significant connection between inflation and the budget deficit (King and Plosser, 1985; De Hann, and Zelhorest, 1990; Dornbusch, Sturzenegger and Wolf, 1990; Hondroyiannis and Papapetrou, 1997).

There are two channels through which two channels affect. The first is the wealth effect, also known as the demand-side effect. This happens when increasing the real value of the stock of bonds boosts perceptions of private wealth, resulting in more spending and as a result increasing inflation (Patinkin, 1965). However, this mechanism is not uncontroversial. Barro (1979) denied the wealth effect and instead proposed the Ricardian Equivalence Proposition, in which he argued for a positive relation between expected inflation and budget deficits; higher inflation expectations imply higher real interest rates and therefore higher debt-service costs. The second is the supply-side effect, which operates through the cost of factors. In this scenario, a deficit triggered by increases in public expenditures can stimulate the demand for scarce resources, thus increasing their cost (Wray, 1997). In terms of empirical research, Kwon, McFarlane and Robinson (2006) found that in highly indebted countries increases in public debt lead to inflation, but that this was less true of advanced economies. In addition, Hondroyiannis and Papapetrou (1994) provide evidence of bidirectional causality between the two variables.

A different view of the connection between inflation and deficits is proposed by Persson et al. (1998). In general, inflation tends to increase real, effective tax rates while eroding the real value of money transfers, for example, because of an imperfect indexation of the tax and transfer systems. Analyzing Sweden in 1994, they conclude that the fiscal gains from inflation might be quite substantial. According to this view, causality can run both ways because higher inflation tends to reduce budget deficits, irrespective of the underlying source of the inflation. This effect contradicts the more conventional Tanzi 
(or Olivera-Tanzi) effect of the nominal characteristics of the tax system according to which higher inflation reduces the real government revenues due to lags in tax collection. This Tanzi effect has certainly become less significant with the modernization of the tax collection system. This brief review of the findings shows that the evidence is mixed. The variety of results arises due to the different data sets, alternative econometric methods, and different characteristics of the countries. Despite the fact that the examination of the budget imbalance and inflation is important to evaluate how the financing of the budget deficit affects inflation, empirical research on this issue in the Lao PDR does not exist, which the authors are aware of.

\section{Modeling and empirical strategy}

Following the literature, the dynamic relation between the government budget deficit and the inflation rate is investigated. The relation is specified as follows:

$\operatorname{Ln} \mathrm{BD}_{\mathrm{t}}=\alpha_{1}+\alpha_{2} \operatorname{lnINF_{\mathrm {t}}}+\mu_{\mathrm{t}}$

and

$\operatorname{Ln} \mathrm{INF}_{\mathrm{t}}=\beta_{1}+\beta_{2} \operatorname{lnBD} \mathrm{t}+\mu_{\mathrm{t}}$

The BD is the government budget deficit. INF is inflation rate. The $\mu$ is an error term. We expect that $\alpha_{2}$ and $\beta_{2}>0$. The government budget deficit is defined as the ratio of the budget deficit to the GDP and inflation rate of Lao PDR. We use the ARDL bounds testing approach to cointegration (Pesaran and Pesaran (1997), Pesaran and Shin (1999), and Pesaran et al. (2001). The empirical formula of the ARDL bounds testing approach to cointegration is given below:

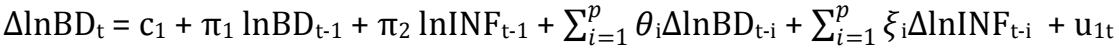

$$
\begin{aligned}
& \text { and }
\end{aligned}
$$

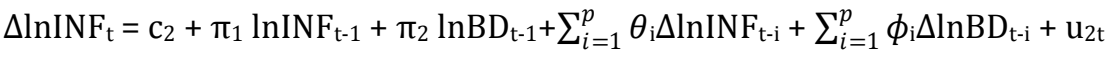

Where $\Delta$ is the first difference logarithm operator.The $c_{1}$ and $c_{2}$ are constants, and $\pi_{1}$ and $\pi_{2}$ are the coefficients on the lagged level dependent and independent variables respectively. The $\theta_{I}$ and $\phi_{i}$ are the coefficients on the lagged dependent and independent variables respectively. The $u_{1 t}$ and $u_{2 t}$ are the error terms. And the $P$ signifies the maximum lag length, which is decided by the user. The procedure for the ARDL bounds testing approach has two steps. The first step uses a F-test for the joint significance of the lagged-level variables. The null hypothesis of the nonexistence of a long-run relation is $H_{0}: \pi_{1}=\pi_{2}=0$ against $\left(\mathrm{H}_{\mathrm{a}}: \pi_{1} \neq \pi_{2}\right)$. Pesaran et al. (2001) generate lower and upper critical bounds for the F-test where the lower bound critical values assume all variables are $\mathrm{I}(0)$, and the upper bound critical values assume all variables are I(1). If the calculated F-statistic exceeds the upper critical bound, then the null hypothesis of no cointegration between the variables is rejected. If the calculated F-statistic falls below the lower bound, then the null hypothesis of no long-run relation is accepted. ${ }^{1}$

Further, we use the VAR and SVAR approaches to analyze the dynamic of the relation between the BD and INF. The SVAR is used to see the sensitivity of the results of the VAR model. The SVAR is superior to the VAR in the sense that the reduced form of the VAR does not consider the structural relation among the variables unless some identification restrictions are assumed. In this sense, the SVAR analysis is an attempt to solve the traditional identification problem. Therefore, the SVAR can be used to predict the effects of the specific policy actions or of important changes in the economy (Narayan et al. 2008).

We define a vector of variables in the SVAR as follows:

$$
\mathrm{x}_{\mathrm{t}}=\left[\mathrm{BD}_{\mathrm{t}}, \mathrm{INF}_{\mathrm{t}}\right]^{\prime}
$$

The infinite order vector moving average (VMA) is represented as follows:

$$
\triangle \mathrm{x}_{\mathrm{t}}=\mathrm{C}(\mathrm{L}) \xi_{\mathrm{t}}
$$

where $\mathrm{L}$ is a lag operator, $\triangle$ is a difference operator, and $\xi_{\mathrm{t}}=\left[\xi_{\mathrm{a}, \mathrm{t}}, \xi_{\mathrm{b}, \mathrm{t}}\right]$ is a $(2 \times 1)$ vector for the covariance matrix of the structure shocks $\sum$. The error term can be interpreted as the relative budget-deficit shocks and the real exchange-rate shocks respectively. We assume that the structural shocks have no contemporaneous correlation or autocorrelation. This assumption implies that $\sum$ is a lower diagonal matrix.

Next, we estimate the following finite-order VAR model:

$$
[\mathrm{I}-\Psi(\mathrm{L})] \triangle \mathrm{x}_{\mathrm{t}}=\mathrm{u}_{\mathrm{t}}
$$


where $\Psi(\mathrm{L})$ is a finite-order matrix polynomial in the lag operator, and $\mathrm{u}_{\mathrm{t}}$ is a vector of disturbance. If the stationary condition is satisfied, then we can transfer equation (8) to the VMA form:

$$
\triangle \mathrm{x}_{\mathrm{t}}=\mathrm{A}(\mathrm{L}) \mathrm{u}_{\mathrm{t}}
$$

where A(L) is a lag polynomial. Equations (7) and (9) imply a linear relation between $\xi_{t}$ and $u_{t}$ as follows:

$$
u_{t}=\mathrm{C}_{0} \xi_{t}
$$

In equation (10), $\mathrm{C}_{0}$ is a $2 \times 2$ matrix that defines the contemporaneous structural relation between the variables. Additionally, we have to identify for the vector of the structure shocks so that it can be recovered from the estimated disturbance vector. We require four parameters to convert the residual from the estimated VAR into the original shocks that drive the behavior of the endogenous variables.

The long run of equation (8) can be written as follows:

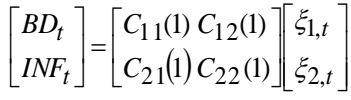

where $\mathrm{C}(1)=\mathrm{C}_{0}+\mathrm{C}_{1}+\mathrm{C}_{2}+\ldots 0$ is the long-run multiplier in the SVAR model ( long-run effect of $\triangle \mathrm{x}_{\mathrm{t}}$ ). We also work with a lower triangular matrix. In the next step, we construct a SVAR and plot the impulse response functions (IRFs) of the variables in the model. The lag length to be incorporated in the analysis of the SVAR model is determined with an Akaike Information Criteria (AIC) because of its better performance in small samples (Liew, 2004).

\section{Empirical Results}

To ensure that the variables are not stationary at I(2),we use the Perronunit-root test (Perron, 1989) and the Z-A unit-root tests (Zivot and Andrews, 1992) because I(2) will cause bias in ARDL application. The unit-root test shows that the BD and the INF are stationary in their different forms with the intercept. This finding implies that our variables have an order of integration that is I(0).

Table 1: Results of the Unit-root test

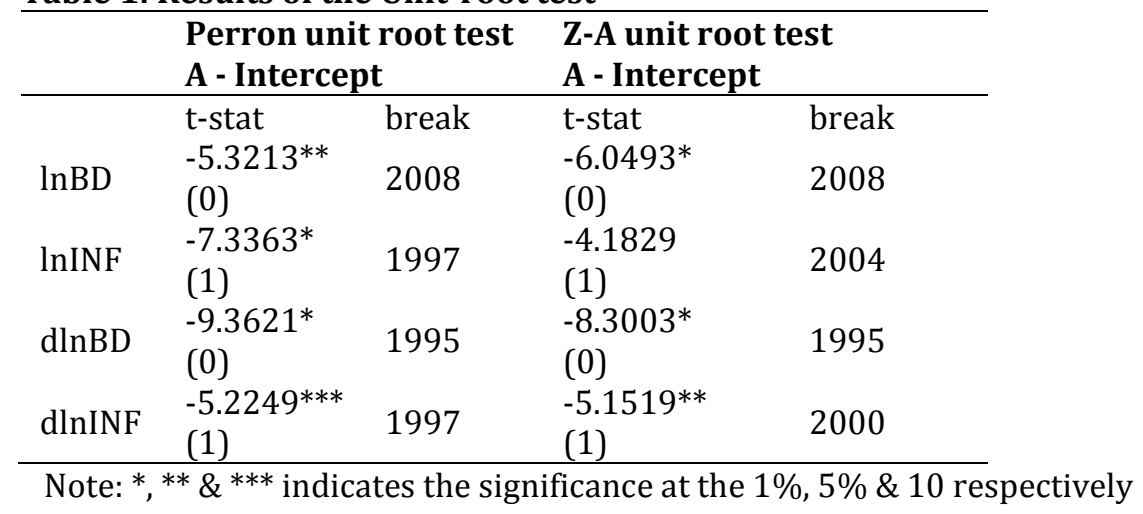

Schwarz Bayesian Criterion (SBC) was used for optimal lag order. The result indicates that one is the optimal lag order. ${ }^{2}$ We produce new critical values (CVs) for the F-test computed by stochastic simulations with 20,000 replications due to small samples. Computed F-statistic for cointegration is shown in table 2 . When the dependent variable is $\operatorname{lnBD}_{t}$, then the calculated F-statistic $\left(\mathrm{F}\left(\operatorname{lnBD}_{t} /{\ln I N F_{t}}_{t}\right)=\right.$ 3.0468 ) is smaller than the lower critical bound. Further, when the dependent variable is $\ln I N F_{t}$, then the calculated F-statistic $\left(\mathrm{F}\left(\operatorname{lnINF}_{\mathrm{t}} / \operatorname{lnBD}_{\mathrm{t}}=0.46395\right)\right.$ is smaller than the lower critical bound. These results suggest that no cointegration exists between the budget deficit $\left(\mathrm{BD}_{\mathrm{t}}\right)$ and the inflation $\left(\mathrm{INF}_{\mathrm{t}}\right)$.

Table 2: Results of ARDL Cointegration Test

\begin{tabular}{lll}
\hline Variable & $\mathbf{I n B D}_{\mathbf{t}}$ & $\mathbf{I n I N F}_{\mathbf{t}}$ \\
\hline F-statistics & 3.0468 & 0.46395 \\
Critical values & $5 \%$ level & $10 \%$ level \\
Lower bounds & 5.6863 & 4.5106 \\
Upper bounds & 6.6111 & 5.2841 \\
Diagnostic tests & & \\
Adj-R & & 0.39671 \\
Durbin-Watson & 0.36065 & 1.4067 \\
\hline
\end{tabular}

Note: ${ }^{*}{ }^{* *}$ and ${ }^{* * *}$ show the significance at $1 \%, 5 \%$ and $10 \%$ level respectively. 
In order to obtain better results, we analyze the VAR-based Granger causality test and report the results in Table 3. Table 3 shows that inflation does cause the budget deficit; but, surprisingly, the budget deficit does not cause inflation.

Table 3: VAR Engle-Granger causality analysis

\begin{tabular}{llllll}
\hline \multicolumn{2}{l}{ VAR Granger Causality/Block Exogeneity Wald Test } \\
$\begin{array}{l}\text { Sample:1980 :2010 } \\
\text { Dependent variable: LBD }\end{array}$ & \multicolumn{4}{l}{ Dependent variable: LINF } \\
\hline Excluded & Chi-sq & Prob & Excluded & Chi-sq & Prob \\
LINF & 7.57376 & 0.0059 & LBD & 0.130459 & 0.7179 \\
All & 7.57376 & 0.0059 & All & 0.130459 & 0.7179 \\
\hline
\end{tabular}

Note: ${ }^{* * *}$ and ${ }^{* * *}$ show the significance at $1 \%, 5 \%$ and $10 \%$ level respectively.

Further, to analyze the accumulated dynamic among these variables, we calculate the IRFs with 10,000 Monte Carlo simulation standard errors. Their study suggests that for a small sample, the properties of the bootstrap confidence intervals are better in comparison with other asymptotic methods. Figure 1 shows the impulse response function (IRF) of the SVAR.

Figure 1: IRFs in SVAR model

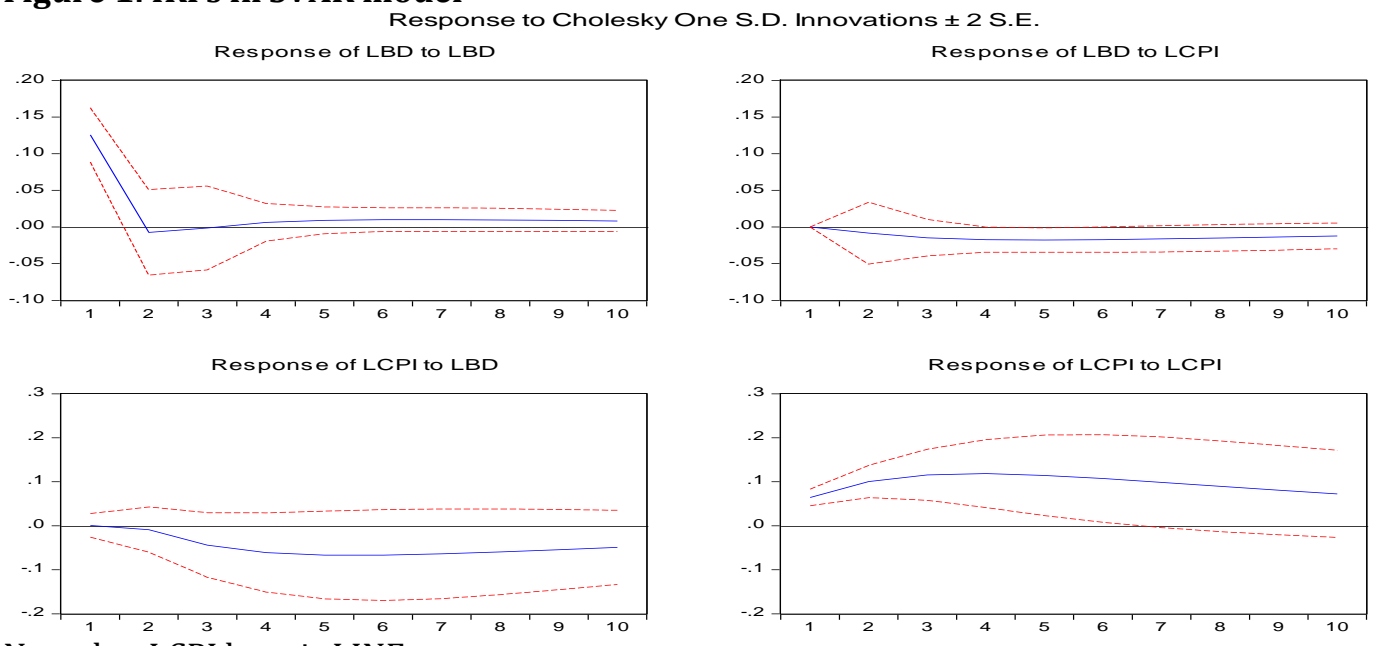

Note that LCPI here is LINF.

Figure 1shows that the accumulated response of the BD to one SD shock in the BD itself is positive and negative only in year 2, whereas the response of the $\mathrm{BD}$ to one SD shock in the INF is negative. The accumulated response of the INF to one SD shock in the INF itself is positive, whereas the response of the INF to one SD shock in the BD is negative. The results of the FEVDs (forecast error variance decompositions) of the SVAR model are presented in Appendix 1.

\section{Conclusion}

This study attempt to examines the inter relationship between a government budget balance and the inflation in Lao PRD. The results disclose that there is no long-run relation between the budget deficit and the inflation rate. The Granger causality test shows that inflation causes the budget deficit; but, surprisingly, the budget deficit does not cause inflation. However, the impulse response results in the SVAR model indicate that the budget deficit has a negative impact over the inflation rate. This impact means that the budget deficit does not cause inflation. However, inflation causes the budget deficit in a negative direction. Nevertheless, the study finds that the budget deficit has not directly caused an increasing inflation rate in Laos. However, if the resources resulting from the additional money issued to cover the budget deficit are used to finance investment projects, then the increase induces raising output. But the ensuing increase in the level of prices does not become permanent; and, therefore, the government enjoys an additional resource from the growth. The government also benefits because the fiscal gains from inflation tends to increase the real, effective tax rates that in turn tend to reduce budget deficits. 


\section{References}

Barro, R. (1979). On the determination of public debt. Journal of Political Economy, 87(5), 940-971.

Catao, L. \& Terrones, E. M. (2003). Fiscal Deficits and Inflation. IMF Working Paper WP/03/65.washington, D.C.

Cevdet, A., Alper, E. C. \& Ozmucur, S. (2001). Budget Deficit, Inflation and Debt Sustainability: Evidence from Turkey (1970-2001). Mimo. Istanbul: Bogazici University.

Chaudhary, M. A. \& Ahmed, N. (1995). Money Supply, Deficit and Inflation in Pakistan. Pakistan Development Review, 34(4), 945-956.

Darrat, A. F. (2000). Are Budget Deficits Inflationary? A Reconsideration of the Evidence. Applied Economics Letters, 7, 633-636.

De Hann, J. \& Zelhorst, D. (1990). The Impact of Government Deficits and Money Growth in Developing Countries. Journal of International Money and Finance, 9, 455- 69.

Dorndusch, R., Sturzenegger, F. \& Wolf, H. (1990). Extreme Inflation: Dynamics and Stabilization, Brookings Papers on Economic Activity: 2, Brookings Institute, 1- 84.

Gupta, K. L. (1992). Budget Deficits and Economic Activity in Asia, London and New York: Routledge.

Hondroyiannis, G. \& Papapetrou, E. (1994). Cointegration, Causality and the Government BudgetInflation Relationship in Greece. Applied Economics Letters, 1, 204-206.

Hondroyiannis, G. \& Papapetrou, E. (1997). Are Budget Deficits Inflationary? A Cointegration Approach. Applied Economics Letters, 4, 493-496.

Khan, T., Bukhari, M. \& Ahmed, S. (2007). Determinants of Recent Inflation in Pakistan. Pakistan Development Review, 34(4), 945-956.

King, R. \& Plosser, C. (1985). Money, Deficits, and Inflation. Carnegie Rochester Conference Series on Public Policy, 22, 147-195.

Kremers, J. J. M., Ericsson, N. R. \& Dolado, J. J. (1992). The Power of Cointegration Tests. Oxford Bulletin of Economics and Statistics, 54(3), 325-348.

Kwon, P., McFarlane, L. \& Robinson, Y. (2006). Public Debt, Money Supply and Inflation: A Cross Country Study and its Application to Jamaica. IMF Working Paper WP/06/121.

Liew, K. S. (2004). Which leg length selection criteria should we employ? Economics Bulletin, 3, 1-9.

Narayan, P., Narayan, S. \& Prsad, A. (2008). A structural VAR analysis of electricity consumption and real GDP: evidence from G7 countries. Energy Policy, 36, 2765-9.

Patinkin, D. (1965). Money, Interest and Prices: An Integration of Monetary and Value Theory, Harper \& Row (1st edition 1955).

Perron, P. (1989). The great crash, the oil price shock and the unit root hypothesis. Econometrica, 57, 1361-1401.

Pesaran, M. H. \& Pesaran, B. (1997). Working with Microfit 4.0: Interactive Econometric Analysis. Oxford University Press, Oxford, 1-505.

Pesaran, M. H. \& Shin, Y. (1999). An Autoregressive Distributed Lag Modeling Approach to Cointegration Analysis. In: Strom S., Ed., Econometrics and Economic Theory in the 20th Century: The Ragnar Frisch Centennial Symposium, Cambridge University Press, Cambridge, 371-413.

Pesaran, M. H., Shin, Y. \& Smith, R. J. (2001). Bounds Testing Approaches to the Analysis of Level Relations. Journal of Applied Econometrics, 16, 289-326.

Persson, M., Persson, T. \& Svensson, L. (1998). Debt, cash flow and inflation incentives: a Swedish example, in G. Calvo and M. King (eds.), The Debt Burden and its Consequences for Monetary Policy, MacMillan Press, 28-62.

Solomon, M. \& De Wet, W. A. (2004). The Effect of a Budget Deficit on Inflation: The Case of Tanzania. Department of Economics, University of Pretoria. SAJEMS NS, 7(1), 100-116.

Sergent, T. J. \& Wallace, N. (1981). Some Unpleasant Monetarist Arithmetic. FRBM Quarterly Review, 5(3), 291-307.

World Bank. (2012). Lao PRD Economic Monitor: Tightening Demand to Maintain Macroeconomic Balance. World Bank, Vientiane.

Wray, L. (1997). Deficits, inflation and monetary policy. Journal of Post Keynesian Economics, 19(4), 543571.

Zivot, E. \& Andrews, K. (1992). Further evidence on the great crash, the oil price shock, and the unit root hypothesis. Journal of Business Economic Statistics, 10, 251-257. 
Appendix I: Variance decomposition in SVAR

\begin{tabular}{|c|c|c|c|c|c|c|c|}
\hline \multicolumn{2}{|c|}{ Variance Decomposition of LBD: } & \multicolumn{5}{|c|}{ Variance Decomposition of LNF: } & \\
\hline Period & S.E. & LBD & LINF & Period & S.E. & LBD & LINF \\
\hline & & & & & & & \\
\hline 1 & 0.125603 & 100 & 0 & 1 & 0.064209 & 0.015928 & 99.98407 \\
\hline 2 & 0.126102 & 99.55593 & 0.444069 & 2 & 0.119469 & 0.553798 & 99.4462 \\
\hline 3 & 0.126958 & 98.2289 & 1.771101 & 3 & 0.171961 & 6.778716 & 93.22128 \\
\hline 4 & 0.128276 & 96.46034 & 3.53966 & 4 & 0.217513 & 12.08242 & 87.91758 \\
\hline 5 & 0.129816 & 94.667 & 5.332995 & 5 & 0.254749 & 15.67938 & 84.32062 \\
\hline 6 & 0.13134 & 93.06042 & 6.93958 & 6 & 0.284403 & 18.10346 & 81.89654 \\
\hline 7 & 0.132719 & 91.70997 & 8.290028 & 7 & 0.307724 & 19.76964 & 80.23036 \\
\hline 8 & 0.133904 & 90.61258 & 9.387425 & 8 & 0.325956 & 20.93973 & 79.06027 \\
\hline 9 & 0.134889 & 89.73677 & 10.26323 & 9 & 0.340175 & 21.77751 & 78.22249 \\
\hline 10 & 0.135693 & 89.04441 & 10.95559 & 10 & 0.351257 & 22.38738 & 77.61262 \\
\hline
\end{tabular}

